\title{
The Antecedents of Extra-Role Organizational Behaviors: A Qualitative Research on Soldier
}

\author{
Ali Murat ALPARSLAN \\ Mehmet Akif Ersoy University, \\ Faculty of Business and Administration, \\ Burdur, Turkey \\ alimurat@mehmetakif.edu.tr
}

\author{
Ali CAN \\ Mehmet Akif Ersoy University, \\ Faculty of Business and Administration, \\ Burdur, Turkey \\ alican@mehmetakif.edu.tr
}

\begin{abstract}
The aim of this study is to reveal the antecedents of extra-role behaviors carried out by the soldiers, who serve in the army without having any financial expectation and have to stay in the barracks due to their compulsory military service. For this purpose, an exploratory research was conducted, in which the detailed interview method was applied on 14 soldiers, who had a certificate of appreciation from their commanders and said to exhibit extra-role behaviors by their commanders. The findings have indicated that exhibited extra-role behaviors were highly related with friendship. Other behaviors are tasks in company, training other soldiers, learning new things, and using the knowledge and skills from civil life in army. When the reasons of these behaviors are examined in detail, it can be seen that the most important factor is friendship, followed by personality, being liked and esteemed by commanders, reciprocity, institute's success and patriotism.
\end{abstract}

Keywords: Extra-Role Behavior, Soldier, Qualitative Research

\section{INTRODUCTION}

The positive work behaviors of members of an organization is one the most important antecedents of job performance, organizational development, efficiency, and adaptation to the change in the literature of traditional business. In this context, the behaviors, which were most commonly expressed and worked on in the literature, are organizational citizenship behavior, pro-social organizational behavior, and extra-role behavior (Organ, 1988, p.4; Dyne \& Cummings, 1990; Brief \& Motowidlo, 1986; Dyne et. al., 1994, p.765). Knowing personal characteristics that influence these behaviors to be exhibited or elements depending on the environment and relationship or cultural factors may contribute to revealing individual and group performance needed in business environment and to reduction of organizational dysfunction (Çetin et al., 2012, p.198). It was stated that one of the most important functions of managers was to overcome the perception of "this is not my job" (Morrison, 1994, p.1563). Organizations need not only members acting within their defined job descriptions, but also the volunteer members undertaking the tasks that are not compulsory for them and 
intending to help others needing for help. Employees voluntarily taking part in positive activities for the purpose of change and development are the persons, whom an organization most wants to have (Morrison \& Phelps, 1999, p.403). Extra efforts and additional positive behaviors of employees of organizations become a human resource, and these all reduce the need for formal mechanisms (Somech \& Zahavy, 2000, p.649; Katz, 1964, p.131-146). In addition to employees' roles in job descriptions, it's stated that helpful and cooperative behaviors are very important from the aspect of increasing the efficiency of an organization.

According to the social exchange theory, if a group member's demands are met, then he or she wants to be beneficial for the organization. If an employee obtains limited output for his/her organization due to his/her ability and capacity, he or she wants to do his/her best for organization by giving extra effort (Bateman \& Organ, 1983, p.588). In upper case again, displaying extra role behavior in the context of social exchange theory, employees suppose that "they would gain group members and supervisors' appreciation since they contribute to achieving group/organization's objectives" (Stoner et al., 2011, p.99). Realization of these mutual expectations yields the results that will satisfy both of the parties. One important factor apart from this lies behind social identity theory. The member, who wants to achieve an identity within group's identity and improve relationship with the group, would like to do more for group (Kane et. al., 2012, p.26). That is, according to social identity theory and social change, those working already can be made more voluntary and willing to do more for their organizations. But, expectations of the employees from their organizations must be realizable and manageable. Moreover, in order to ensure that result, the employees' requests from their organizations must be manageable and satisfied, and their desire of being regarded and recognized as a member of the organization must also be established.

After 1980s, increasing number of studies about the concept of "organizational citizenship behavior" brought more increase in interest of extra-role behavior (Finkelstein, 2011, p.20). The dimensions and examples of this behavior have been mentioned greatly in related literature, on which many studies have been done. In these studies, Researches were carried out on usually employees, the people that serve in exchange for material elements. Within the scope of social change theory, if a salary is paid to someone, then the one paid wants to serve in exchange for this. It will be the most important contribution of this study to reveal why the people, who don't serve for any price due to their special status but serve due to a compulsory mission such as military service, want to do more for their organizations. What are the factors that motivate them to display extra role behaviors, when people work without any expectation? Answering this question by conducting exploratory qualitative research will show business managers and academics in detail "why people display pro-social behaviors even in the most difficult situations", and will enrich the organizational citizenship behavior literature.

\section{EXTRA-ROLE ORGANIZATIONAL BEHAVIOR}

Behaviors referred as extra-role behavior in related literature were discussed at two basic levels as organizational citizenship behavior and counterproductive behavior (Chen \& Spector, 1992, p.119). However, in many definitions in the literature, it has been seen that the extra-role behaviors are considered from the aspect of benefit of 
organizations and assessed within the scope of organizational citizenship behavior. Moreover, it has also been cited with similar terms in many sources (Organ, 1988: 101; Morrison, 1994, p.1543; Zhu, 2013, p.23; Davoudi, 2012, p.66).

Organizational citizenship behaviors are innate, when displayed, it's not specified in a formal reward system, and they are directed for the benefit of organization (Organ, 1988; Bowling, 2009, p.119). Citizenship behaviors are basically the behaviors, which employees of an organization display individually (Cetin \& Fikirkoca, 2010, p.43). Organizational citizenship behaviors were evaluated in 7 different themes (Organ, 1988; 1990). Here are the themes that Podsakoff et al. (2000, p.516) obtained from the literature:

- Helping behavior: consists of voluntarily helping others with, or preventing the occurrence of work-related problems.

- Sportsmanship: involves willingness to tolerate the inevitable inconveniences and impositions of work without complaining and being willing to sacrifice their personal interest for the good of the work group, and not taking the rejection of their ideas personally.

- Organizational loyalty: consists of loyal boosterism and organizational loyalty, spreading goodwill and protecting the organization and the endorsing, supporting, and defending organizational objectives construct.

- Organizational compliance: appears to capture a person's internalization and acceptance of the organization's rules, regulations, and procedures, which results in a scrupulous adherence to them, even when no one observes or monitors compliance.

- Individual Initiative: of all organizational citizenship behavior dimensions, it is the most emphasizing dimension that stresses extra-role behavior. Volunteering to take on extra individual initiative, extra actions in organization in the cause of creativity and innovation, extra incentive for anyone to succeed, extra responsibilities, and prompting others for extra effort.

- Civic Value: a willingness to participate actively in its governance, attending meetings, engaging in policy debates, expressing one's opinion and idea, monitoring environmental opportunities and threats, following the most important developments, feeling himself as a part of organization, being aware of having more responsibilities than defined.

- Self-development: includes voluntary behaviors that employees engage in to improve their knowledge, skills, and abilities, seeking out and taking advantage of advanced training courses, keeping abreast of the latest developments in one's field and area, or even learning a new set of skills so as to expand the range of one's contributions to an organization.

Organizational citizenship behavior was examined in two categories as organization-oriented and people-oriented (Zhu, 2013, p.24). In the first dimension, it includes conveying useful information to colleagues and the cooperation efforts, as well as helping them. The second dimension is related with the organization, and it refers to adherence to non-formal norms formed in organization and extra effort for improving outcomes (Resick et al., 2013, p.954). These kinds of extra-role behaviors for the good of colleagues have been named as "pro-social behaviors" in the literature. Pro-social 
behaviors, which include matters such as helping, encouraging, consoling, sharing information and cooperation mostly, are faces of organizational citizenship behavior towards individuals and groups (Dunfield \& Kuhlmei, 2013, p.1766). Whereas, those defined as "pro-social service behaviors" in the literature are in-role behaviors, extrarole behaviors and behaviors which individuals exhibit for customer in order to increase the effectiveness of the service processes and their colleagues (Bettencourt \& Brown, 1997, p.41). In this study, the organizational citizenship behaviors towards the organization, named "extra role behaviors" in the literature, were examined. In this behavior form, the members of the organization act in the interest of organization without considering their personal interests. This behavior that increases the effectiveness of organizations by reducing rifts among organization members has similar function to oil for better working of the social wheels in organization (Finkelstein: 2011, p.20).

Given the definitions in studies on extra-role behavior, these have been defined as behaviors that attempt to benefit the organization and go beyond existing requirements of the job description, that are discretionary and for the benefit of organization, that are not directly or clearly recognized by a formal reward system, that don't require any punishment if not performed, and that are positively directed towards individual, group or organization in order to achieve the organization's goals and objectives (Dyne \& Lepine, 1998, p.108; Somech \& Zahavy, 1999). It has been stated as behaviors triggered by senses of particularly the organizational commitment and personal achievement (Organ, 1997, p.86). These have been seen as behaviors that are displayed in a proactive manner by members of organization such as helping, seeking help, playing a role in orientation of newcomers, giving positive speech about members of group while out of organization, taking initiative, making extra duties without complaining, saving organization's resources, protecting organization from possible risks, instant collaboration, constructive/innovative ideas, making suggestions, gaining more knowledge and skill for the benefit of organization (Katz, 1964, p.131-146; Chiaburu et. al., 2007, p.2283, Chen et al., 2009, p.120; Bowling, 2010, p.119; Turnipseed \& Rassuli, 2005; Bateman \& Organ, 1983).

Extra-role organizational behavior was examined in four dimensions as supportive (encouragement, stimulating), preventive (not to allow members to give negative speech, protecting organization and its members), showing sympathy (altruism, establishing, maintaining and managing good relationships) and combative (exchange and innovation, making suggestions, fighting against obstacles, not to remain silent). Supportive behavior occurs in a proactive way, whereas preventive behavior is protective and prohibitive in structure. While impressment (showing sympathy) behavior regards humanitarian relations and emphasizes the spirit of collaboration, struggle behavior refers to new proposals and actions supporting change (Dyne \& Lepine, 1998, p.108). As the common characteristic of all these dimensions, in other words, it has been stated that, in order for a behavior to be an extra-role behavior, it must be acted in a voluntary way, be useful for the organization and, when extra-role displayed, there should be no formal reward or punishment (George, 1996, p.78-80).

Therefore, extra-role behaviors have been reciprocated with salary system, which is part of the work of member of organization. Besides, it dissociates clearly from job descriptions expressed precisely to individual in organization and shapes in-role behaviors (Katz \& Kahn, 1978, p.24; Bateman \& Organ, 1983). But, behaviors stated as 
extra-role must be thought as in-role behaviors of employees. Although it has been said that it is difficult to make this separation (Dyne et.al., 1994), while differentiating inrole and extra-role behaviors, whether the job description of employees is identified with a broad perspective is very important. That is, the difference between expectations and standards is decisive factor. An employee's work should be defined not only in the technical sense but also in the social context (other issues he/she can feel himself/herself responsible) (Morrison, 1994, p.1544). Manager may incorporate extra voluntary efforts of employees into their job descriptions by means of psychological contracts. In this case, extra efforts of employees may be transformed into a usual situation (Srikanth \& Jomon, 2013, p.30).

\section{LITERATURE REVIEW: ANTECEDENTS AND CONSEQUENCES OF EXTRA-ROLE ORGANIZATIONAL BEHAVIOR}

Making a member of organization to become its citizen ensures him/her obedience organization's rules, goals and targets and his/her important role for the organization. While obedience is important for employees in order to enhance in-role behaviors, commitment and participation bring out actions that are displayed voluntarily (such as helping others, discourses for increasing organizational reputation, protecting the organization from the hazards, information sharing, new ideas, etc.) (Dyne et al, 1994, p. 767). In commitment element, while normative and obligation commitment are motivating in-role behaviors, it's necessary to increase the emotional commitment in order to increase extra-role behaviors (Morisson, 1994, p.1547), because extra-role behaviors are displayed as a result of emotions (Bowling, 2010, p.127). In order to demonstrate this dedication, employee must feel himself/herself important for his/her organization (Karaman \& Aylan, 2012, p.47). So the employers and managers can get involved. In addition to these, procedural justice in the organization has come to the fore as an important encouraging element of extra-role behavior as well (Kim \& Mauborgne, 1996, p.500). If employees perceive inequality in organization, this significantly reduces their extra efforts and makes them indifferent. (Scholl, 1981). Managers emphasizing on ethical and moral values and acting in a consistent way outline a role model for their employees and play an important role in exhibiting positive behaviors of subordinates (Hannah et. al., 2011, p.556-557; Yeşiltaş et.al. 2013, p.346). This consistency reinforces the sense of trust in subordinates. With the improvement of the justice perception in organization, employees' adherence to given decisions increases, and commitment to the decisions is effective in the formation of extra effort (Kim \& Mauborgne, 1996, p.511). Remarkable organizational support perceived has an increasing effect on this effort, as a matter of fact, it is stated that this is one of the most important triggering events. Along with justice and support perception, job satisfaction of the people, who will much work for their organization, must be much as well (Witt \& Wilson, 1989, p.248). However, it has been also stated that satisfaction alone is not sufficient, employees must have conscientious characteristic (Organ, 1997, p.94; Bowling, 2010, p.127). According to this, when it is considered from the aspect of social exchange theory, as the quality of reciprocal relationship of the employee and manager grows, both of material and spiritual attitudes towards each other increase accordingly (Tremblay et. al.., 2010, p.423). For example, as the employee's manager shows up the effort for his/her employees to satisfy from their works, employees reward the manager by displaying extra-role behavior (Vey \& Campbell, 2004, p.120). If managers provide good working conditions, and constitute 
enjoyable and a pleasant working environment, employees' behavior of helping each other, pro-social tendencies in other words, will occur spontaneously (Barbuto \& Story, 2011, p.26).

As well as organizational factors, the individual factors are also important in extra-role behavior of employees. Depending on the differences in employees' characteristics, values, attitudes, life experiences, and factors motivating them, there are differences in displaying this behavior (Morrison, 1994, p.1564; Penner et. al., 1997, p. 113). It has been stated that business character and person's own character must be compatible. Also the required importance must be given to socialization process in order for an employee to take on compatible character with organization. A person's self-efficacy and competence that he/she perceives as organization are also important. If the person does not believe himself/herself or group, he/she doesn't make an extra effort (Somech \& Zahavy, 2000, p.657; Çetin \& Fikirkoca, 2010, p.41). Internal motivating factors are more important than external ones from the aspect of employees' exhibition of extra-effort. There are some researches showing that the pro-social behaviors depend on the pro-social personalities (person making intense empathy, taking on responsibility for others, loving to help (Penn, 2002; Finkelstein, 2011, p.19). Especially in difficult times, members of the organization must endeavor much more than usual and take on initiative and extra-role in order to sustain the life of organization and to enable it to be successful again (Waldman, 1994).

Exhibited optimistic efforts for the favor of the organization will enable group/organization to have a collective structure, and also increase mutual responsibility feelings of team members, clinch the senses of cooperation and trust, make members feel the identity of group/organization deeper. The commitment of member, who has gained group identity rather than corporate identity, will increase. The member having increased level of commitment will be more voluntary and display extra-role behavior (Kane et. al., 2012, p.27-36; Leung, 2008, p.51). This will provide the social and psychological environment in this spiral organization with a positive effect (Organ, 1997, p.90). Even if the organization members are not in formal expectation of reward, the discretions from their colleagues and managers are the factors strongly motivating them (Stoner et. al., 2011, p.99).

\section{METHODOLOGY}

This study is in the form of phenomenology aimed to explain the phenomenon of extra-role behavior (behaviors, reasons for behavior, and conditions of behavior) in the context of qualitative research methods. The fact that study was carried out on soldiers doing compulsory military service in army is a critical issue that makes this research original. The selection of soldiers creating research sample was given attention in order to reveal accurate findings. Therefore, of all purposive sampling methods used in qualitative research, criterion sampling method was deemed suitable. This criterion is that they are soldiers, who have certificate of appreciation from their commanders because of their extra-role behaviors. In fact, meaning of the fact that study was carried out on such a sample making is that it is also working with a sampling that is suitable for critical state sampling. Critical state sample; based on the form of a judgment such as "If that occurs here, it can definitely occur in other similar situations" can be used (Yıldırım \& Şimşek, 2011, p.110). Enabling soldiers doing their compulsory military service, staying away from their families and people they love, having different 
relationship environment to display voluntary behaviors has been considered to be important from the aspect of revealing the issues that will affect the people's working in a voluntary way.

Considering that a scientific research would give less accurate findings through assumptions, information from soldiers, who exhibited voluntary behavior previously and took certificate of appreciation and were proposed as model by commanders, have been seen more appropriate. In this context, 14 soldiers were included in the study. These soldiers were informed face-to-face about what the extra-role behavior is and which behaviors are referred as extra-role. Then, interviews began in the semistructured interview form. There were 3 open-ended questions in the context of research focus, besides the demographical variables such as rank, hometown, age and educational status. Questions were asked to the soldiers in the atmosphere of chatting.

Where it makes sense, the questions were asked to get more detailed but in focus of interest answers. At this point, it was benefited significantly from flexibility characteristic of qualitative research design this research questions are as follows:

1. Have you ever exhibited extra-role behavior during your military service? If yes, could you tell us what these are?

2. Although it was not your responsibility, why did you voluntarily exhibit this behavior? What were the reasons for this kind of behavior you exhibited?

3. What are the circumstances and conditions that prevent you from exhibiting that kind of behaviors or encourage you exhibit voluntary behaviors during your military service?

Although qualitative research cannot reach the findings that can be generalized, there will be significant conclusions about what the reasons were, why soldiers chosen exhibited extra-role behaviors, under what conditions they performed or stayed away from these kinds of behaviors. These interviews were conducted face-to-face with 14 soldiers (at least 30 minute) upon the permission of their commanders. The soldiers were asked for answering without any hesitation. In order to increase the reliability and validity of the study, the findings obtained as a result of the study have been shared with both of participant soldiers and their commanders, and their approval and recommendations have been obtained. From the aspect of the education level of soldiers, there were 1 master degree, 5 graduates, and 1 high-school graduate. Soldiers aged between 20 and 26 are gendarmerie, infantry corporal and infantry sergeant.

Interviews were conducted separately with each of them. Interviews were recorded, and the audio recordings were then transferred into text after listening several times. Qualitative data analysis process was conducted by performing content analysis on texts in detail. In this process, words, sentences or paragraphs that have meaningful coherence and similarities with each other were examined firstly, and separate coding was made for each of the each of questions in survey. Thus, the available data's "description" process was completed. Then, the categories were formed by combining the codes in the same direction and focus. Another data analysis process, the "classification" process was carried out. In this process, descriptive analysis was accomplished by calculating percentages of related codes and frequencies. It should be emphasized that the description was formed according to codes and categories that have not been determined previously but taken out from new data obtained from interview texts. In order to ensure the validity of the findings, as far as possible, the codes and 
categories have been determined and specified by considering their antecedents in organizational citizenship literature. The generated codes and categories are presented to the reader in a systematic way in the tables below. So the descriptive analysis process was completed. Interpretation of these representations was carried out by supporting it through quotations directly taken from interviews. Then, confirmation was taken from related commanders and soldiers by presenting these conclusions, codes and categories to them.

First, it was tried to determine perceptibly what extra-role behaviors the soldiers exhibited during their military services were. Rather than working based on assumptions, researching voluntary behaviors exhibited in the past and the reasons for these behaviors were considered to be more scientifically appropriate. Participants, who had certificate of appreciation already, expressed what these behaviors were. Table 1 demonstrates these behaviors and categories obtained from data.

Table 1: Types of exhibited extra-role behavior

\begin{tabular}{|c|c|}
\hline Behavior Categories & Behaviors (Definitions) \\
\hline $\begin{array}{l}\text { Friendship } \\
f=14,45 \%\end{array}$ & $\begin{array}{l}\text { Being on duty instead of ill/tired friend }(\mathrm{K}: 2, \mathrm{~K}: 3, \mathrm{~K}: 5 \text {, } \\
\mathrm{K}: 9, \mathrm{~K}: 10, \mathrm{~K}: 13, \mathrm{~K}: 14) \\
\text { Being on duty instead of friend, who is fasting in } \\
\text { Ramadan.(K:9) } \\
\text { Supporting friend in financial trouble }(\mathrm{K}: 4, \mathrm{~K}: 6, \mathrm{~K}: 9) \\
\text { Cleaning the related area instead of ill/tired friend }(\mathrm{K}: 5 \text {, } \\
\mathrm{K}: 9, \mathrm{~K}: 10)\end{array}$ \\
\hline Affairs of Institute/Platoon & $\begin{array}{l}\text { Checking position and guard posts }(\mathrm{K}: 3) \\
\text { Helping friends in their works. }(\mathrm{K}: 8, \mathrm{~K}: 9)\end{array}$ \\
\hline$f=7,23 \%$ & $\begin{array}{l}\text { Taking on a mission without any knowledge about it } \\
\text { before. }(\mathrm{K}: 7, \mathrm{~K}: 10) \\
\text { Helping civilian officers }(\mathrm{K}: 9) \\
\text { Carrying coals another place in order them not to get } \\
\text { wet. }(\mathrm{K}: 11)\end{array}$ \\
\hline $\begin{array}{l}\text { Improving/Training of } \\
\text { Soldiers } \\
f=4,13 \%\end{array}$ & $\begin{array}{l}\text { Teaching illiterate soldiers how to read and write }(\mathrm{K}: 11 \text {, } \\
\mathrm{K}: 12) \\
\text { Motivating friends }(\mathrm{K}: 4) \\
\text { Improving friends' military knowledge. }(\mathrm{K}: 4)\end{array}$ \\
\hline $\begin{array}{l}\text { Learning new } \\
\text { information/attitudes } \\
f=2,6 \%\end{array}$ & Going to armed tasks $(\mathrm{K}: 1, \mathrm{~K}: 14)$ \\
\hline $\begin{array}{l}\text { Sharing knowledge/skill } \\
\text { from civilian life } \\
\mathrm{f}=\mathbf{4}, \mathbf{1 3} \%\end{array}$ & $\begin{array}{l}\text { Implementing new applications with computer } \\
\text { knowledge }(\mathrm{K}: 8) \\
\text { Making some sort of repair by means of skills learnt in } \\
\text { civilian life }(\mathrm{K} 2, \mathrm{~K} 3, \mathrm{~K}: 6, \mathrm{~K} 9)\end{array}$ \\
\hline
\end{tabular}

Exhibited extra-role behaviors are seen under behavior categories as friendship, affairs of institute/platoon, improving/training of soldiers, learning new information/attitudes, passing along knowledge/skill from civilian life. These categories were extracted from the data determined previously. It has been seen that $45 \%$ of the resulting behaviors were friendship-oriented behaviors, $23 \%$ were ones related to institute's/team's/branch's success, $13 \%$ were ones intended for the 
development/improving of other soldiers, $13 \%$ were ones related to passing along knowledge/skill from civilian life, and $6 \%$ were ones about learning new information and attitudes. It has been seen that majority of the behaviors are those intended to help and protect friends and friendship. Among all these behaviors, being on duty for his friend behavior has been mostly seen one. It has been observed that the main reason behind this behavior was the "sympathy" phenomenon; the most basic social need such as "deprivation of liking and being liked". This inference can be supported through direct quotes from participants.

For example, K5 said "the fact that my friend was ill saddened me, I like him very much. So I told my commander that I wanted to be on duty instead of my friend," K14 stated that "as I exhibited this kind of behavior, I realized that I was liked and appreciated by my friends". In the same manner, K2 said "those exhibiting such behaviors are much loved and regarded by his colleagues ", while K6 said that "Although this was not my duty, I repaired the tea machine in order for my friends to drink tea, so I became a much-liked person in the institute". On the other hand, supporting the soldiers having poor financial sources is another behavior come to the fore. 3 soldiers provided support financial to other soldiers in difficulty. They expressed that "I like to share my bread", "I know what the poverty is, because I experienced before. So, I organized my other friends to help others". "I know what poverty is since I have experienced it. That's why; I organized my other friends to help my friend". As it can be understood here, one of the most important needs of soldiers is sense of liking, being liked, helping and gladdening. Strengthening the bonds of friendship of soldiers and creating an atmosphere of peace between them can constitute the ground for the satisfaction of those needs.

Another important type of behavior displayed by the soldiers is related with the tasks of squad/team. At this point, the friendship issue has come into prominence again. Soldiers help their fellows in order for them to fulfill their missions. For example K8 stated that "in supervision, in order for the institute not to fail and in order not to leave my friend alone, I carried his gun instead of him and I held his arm and took him with me.", K9 told that "I made cleaning for my friend, and that was my friend's responsibility. Hence he wasn't rebuked by commanders". As well as helping their fellows, although they didn't have any knowledge about that mission, they took over their fellows' responsibility for better. K7 said that "I took over kitchen duties instead of my friend, so my friend could go to sick leave", while K10 stated that "Because I liked my commander, I told him that I could take on the responsibility of boiler room due to absence of anybody in charge". At this point, the strength of the emotion of liking the friend and commander is emphasized. The statement given by $\mathrm{K} 9$ that "I helped female civilian officer because I looked at her as a sister" is an important indicator of how effective the both of the senses of liking and being liked in such behaviors.

Soldiers also undertook extra-role behaviors for both education and improvement of soldiers. They taught their fellows to read and write, and inspired them to improve their military knowledge and to motive them in their works. K12 told that "I taught three of my friends how to write and read because I wanted to help them", K11 said that "Being helpful towards my friends, teaching them to read and write and our National Anthem made me very happy". Using these expressions, it has been seen that these benefits made soldiers, who exhibited these behaviors, happy. A number of soldiers took on extra-behaviors in order to learn new information and to experience new conditions. During the interviews, K1 stated that "Doing constantly same tasks is 
boring for me, and I want to learn new things and participate in new tasks." However, it should be noted that it is also significantly linked to personality. Because the participants $(\mathrm{K} 1, \mathrm{~K} 14)$ exhibiting this same behavior stated in interview that "I have sociable, bouncy personality, I like to help people."

Finally, behaviors such as transferring knowledge and skills in civilian life to military service were also seen. Four soldiers stated that if the tasks given to them would be their favorite works, then they could gladly undertake these tasks. In a supporting way of this speech, K9 said that "I know the construction and repair works, and I fixed the shower and faucets although nobody ordered me to do so", while K6 stated that "nobody wants to be responsible for making the tea, because the accounting and dish preparation are difficult works. I undertook this task because my fellows would drink tea and my commanders would appreciate me". K2 and K3 said that "For better inspection results, I told my commander that I could repair the barracks, and I did", "Our patrol car broke down, and I noticed that a part of its engine must be replaced. I said to my commander that I could change it if he could find spare part, and then I fixed it later."

The second question of the research was "what the underlying causes of these kinds of behaviors were". Reasons were classified into a variety of codes, and then these codes were transformed into categories in a manner of meaningful codes. According to designated codes, the personality, to be liked and praised by commanders, affection of friendship, success of institute/platoon, mutuality, patriotism categories were composed. The frequency of each code and all reasons of each category were presented in table 2 .

Table 2. The Antecedents of Extra-Role Behaviors Displayed

\begin{tabular}{|c|c|c|c|}
\hline \multirow[t]{3}{*}{ Categories } & Codes & $f^{*}$ & Percent \\
\hline & Liking to help & 5 & \\
\hline & Being hardworking/enterprising & 2 & \\
\hline \multirow[t]{3}{*}{ Personality } & Being open to learn & 2 & $20 \%$ \\
\hline & Upbringing style & 2 & \\
\hline & Faith & 1 & \\
\hline \multirow{3}{*}{$\frac{\text { Being liked and praised by }}{\text { Commanders }}$} & Gaining their trust & 3 & \\
\hline & Being appreciated & 6 & $16 \%$ \\
\hline & Not to be scolded & 1 & \\
\hline \multirow{6}{*}{ Affection of Friendship } & Making friends happy & 3 & \multirow{6}{*}{$\underline{33 \%}$} \\
\hline & Making friends feel comfortable & 2 & \\
\hline & Improving friends & 3 & \\
\hline & Ensuring a peaceful environment & 6 & \\
\hline & Becoming a beloved person & 4 & \\
\hline & Not to make himself scorn & 2 & \\
\hline \multirow{3}{*}{ Success of Institute/Platoon } & Succeeding in supervision & 4 & \multirow{3}{*}{$\underline{12 \%}$} \\
\hline & Improving works & 1 & \\
\hline & Not to embarrass commander & 2 & \\
\hline \multirow[b]{2}{*}{ Mutuality } & Previous aid of the friends & 4 & \\
\hline & $\begin{array}{l}\text { Previous favor of the } \\
\text { Commander }\end{array}$ & 4 & $13 \%$ \\
\hline Patriotism & Serving for country & 4 & $6 \%$ \\
\hline
\end{tabular}

*f: The number of expression of behaviors. 
Knowing the underlying causes of the extra role behaviors exhibited by soldiers is necessary in order to prepare a proper ground for them to exhibit these behaviors. Therefore, these factors were put forth in detail in this study, and then were categorized to form meaningful wholes. In Table 2, the reasons (codes) and categories formed by these reasons are presented. It has been seen that the most important reasons seem to be the ones related with the friendship (\%33). The majority of behaviors $(\% 48)$ are already seen as behaviors intended to protect the bonds of friendship and friends. As mentioned previously, the necessity of liking and being liked plays an important role in these behaviors. They mostly meet this up with their friends. To make their fellows happy, to make them feel comfortable, to protect them from being reprimanded and so, to be a respected man and to help create a peaceful setting are the main reasons behind voluntary behaviors they exhibited.

Another important reason has been found to be the personality of soldiers (20\%). The majority of the soldiers replied as" I did because of my willingness". This can be explained with the personality in most appropriate way. Then, they stated the characteristics such as entrepreneur, hardworking, liking to help people and open to learning. Besides them, three of soldiers expressed that they behaved in a voluntary way because of upbringing style. So, upbringing is important in gaining a personality that will exhibit these kinds of behaviors in a voluntary way. Lastly, one of soldiers emphasized that he behaved in voluntary way due to his belief. He stated that, according to his belief, the military service was very divine, so he was willing to do his best, even more."

Another category, which has significant proportion (16\%), is related with being liked and regarded by commanders. Although soldiers meet their needs of being liked and regarded thanks to their friends, they significantly want to be liked and regarded by their commanders as well. To be appreciated especially by commanders is an important factor for displaying voluntary behaviors. To gain commanders' trust, to be liked by commanders, and not to be scolded by commanders are motivational conditions for these behaviors. However, it should be noted at this point that being liked and regarded phenomenon occurs mutually. In other words, soldiers may become more ready to do his best in response to a favor or support previously made by the commander. The same situation is acceptable for friends. This mutuality behavior has relatively an important rate $(13 \%)$ for voluntary behaviors. From this point, commanders must increase their help and kindness, which are investments for the future towards soldiers. Thus, enabling the soldiers to develop sense of not being ashamed to commanders and reciprocating, it may be made soldiers to perceive their extra-role behaviors as in-role behaviors.

Finally, it has been observed that there are behaviors originated from unit's success $(12 \%)$ and the patriotism of soldiers. Soldiers expressed that the reasons for why they exhibited voluntary behaviors were that their military unit become successful in military supervision, for current tasks to be executed better, and for their commander not to be embarrassed to his supervisors. Some soldiers have been performing these kinds of behaviors with the consciousness of patriotism. In this point, it has been seen that persons who perceived military service from the aspect of his faith and who were sent to the army with teachings of their parents related to military service, have this awareness much more. In other words, personality elements are effective in terms of having this consciousness. However, because it is state of peace, it should be considered 
normal that the "patriotism" is not mentioned very often. But, it has been seen that there is no need to another extra reason for soldiers, who have this awareness.

Last question of the study aimed to reveal what circumstances and conditions that encourage soldier exhibit voluntary behaviors should be. For this reason, it will be a richer assessment to encode circumstances and conditions, which are both encouraging extra-role behaviors and preventing them from exhibiting these behaviors, separately. Findings together with participants, whom are owner of expressions, are presented in Table 3.

\section{Table 3. Circumstances and Conditions which encourage/prevent extra-role behaviors}

\begin{tabular}{|c|c|}
\hline$\frac{\text { Conditions encouraging extra role }}{\text { behaviors }}$ & $\frac{\text { Conditions preventing extra role }}{\text { behaviors }}$ \\
\hline $\begin{array}{l}\checkmark \text { Being more clear about the commanders' } \\
\text { expectation }(\mathrm{K}: 1)\end{array}$ & $\begin{array}{l}\text { * Commanders' } \text { aggressive } \\
\text { during an event. }(\mathrm{K}: 1, \mathrm{~K}: 4)\end{array}$ \\
\hline $\begin{array}{l}\checkmark \text { Environments with strong relations } \\
\text { between friends. (K:1: K:4) }\end{array}$ & Friends' impassive manners $(\mathrm{K}: 8, \mathrm{~K}: 9)$ \\
\hline$\checkmark$ Commanders' fairness $(\mathrm{K}: 3, \mathrm{~K}: 8, \mathrm{~K} 12)$ & * The perception of being abused (K:2) \\
\hline $\begin{array}{l}\checkmark \text { Discrimination between hardworking and } \\
\text { non-hardworking soldiers by } \\
\text { commanders. }(\mathrm{K}: 3, \mathrm{~K}: 8)\end{array}$ & $\begin{array}{l}\text { Commanders' unfair behaviors }(\mathrm{K}: 2 \text {, } \\
\mathrm{K}: 4, \mathrm{~K}: 12)\end{array}$ \\
\hline $\begin{array}{l}\checkmark \text { The works, which are enjoyed in civilian } \\
\text { life. }(\mathrm{K}: 5, \mathrm{~K}: 11)\end{array}$ & $\begin{array}{l}\text { Commanders' holding everyone } \\
\text { account in case of a fault }(\mathrm{K}: 2)\end{array}$ \\
\hline $\begin{array}{l}\checkmark \text { Commanders' more indulgent attitudes } \\
\text { towards soldiers. }(\mathrm{K}: 3, \mathrm{~K}: 10)\end{array}$ & $\begin{array}{l}\text { Getting angry of different commanders } \\
\text { with different situations. }(\mathrm{K}: 2)\end{array}$ \\
\hline \multirow[t]{4}{*}{$\begin{array}{l}\checkmark \text { Being appreciated by commanders (K:8, } \\
\mathrm{K}: 12)\end{array}$} & $\begin{array}{l}\text { Remaining each job on a person who } \\
\text { did it. }(\mathrm{K}: 4, \mathrm{~K}: 8, \mathrm{~K}: 12)\end{array}$ \\
\hline & $\begin{array}{l}\text { Negative feedback for an action. (K:6, } \\
\text { K7) }\end{array}$ \\
\hline & $\begin{array}{l}\text { Nepotism between soldiers in the same } \\
\text { cohort. (K:12) }\end{array}$ \\
\hline & \&o \\
\hline
\end{tabular}

Antecedents, which encourage soldiers to exhibit these behaviors, focus on either friendship or commanders' behaviors. When bonds of friendship are strong, commanders are fair and do distinguish working person from do-nothing person, or display more understanding attitude, soldiers realize that their commanders appreciate them, so they are seen as more willing to exhibit extra-role behaviors. Besides, if tasks of soldiers in charge are works that they like to do and know how to do in civilian life, then they perform these tasks in voluntary way. In order to support these findings, direct quotations from interviews with participants can be examined. For example, saying "I want my commanders to be more understanding and fair towards us. If they distinguish working person from do-nothing person, it would be very good. When I am exposed to the same attitude, my desire to do something would be broken down. At least, while they use their discretions, the fact that they distinguish working person from do-nothing person motivate us" K3 actually talked about the essence of work. Soldiers, who don't know what commanders, are angry with or not stay away from exhibiting extra-role behaviors (K1). K8 stated that "While my commanders are assigning us our tasks, I 
want him to be fair". K2, K4 and K12 especially expressed that they lost their enthusiasm because of injustice. K4 said that "injustice makes me very sad, and I don't have any enthusiasm to do my own tasks". K2 also used the expression of "My commander's injustice manner dispirits me. Although $I$ expressed this to my commander, his remaining indifferent upsets me much more. In relation to justice, it has been also emphasized that works remain on whoever does. K4's statement was "if you try to do all tasks or help someone about a duty which is not in charge of you, then this tasks remains on you", K12 expressed that "it's not important how works are carried out, but it is important how they end, so the same persons continuously do these works" and K8 expressed that "if our commanders assign us in nepotism, then always same person works", and these are the proofs of how often justice phenomenon were emphasized.

While injustice is so important phenomenon, being appreciated may also be a very important and positive trigger. $\mathrm{K} 8$, by saying that "As my commanders appreciated me, my enthusiasm to do more increases much more", emphasized the importance of positive feedback. In a supportive way to this finding, K12 said that "My commander appreciated me, I became very happy and I wanted to do my best". Before appreciation, it was also considered important that commanders demonstrate more understanding attitude. K10 said that "As my commander displays good attitudes and behaviors towards me, I am ready to do everything in voluntary way", as seen above, while K3 also stated that fair and understanding attitude would be more effective. Considering the reasons preventing soldiers from exhibiting voluntary behaviors, aggressive behavior and showing immediate response are seen as major obstacles. In this regard, K1's statement "Because I abstain from my commander's aggressive manner, I cannot display the behaviors I want to do willingly, K4's expression "When my commander shows me rigid stance, I don't feel like doing something" show us that these kinds of statements demoralize soldiers, who are already in far away from their families. The fact that K6 and K7 were scolded due to behaviors exhibited in a voluntary way restrained them from exhibiting these behaviors.

Not knowing what commanders expect from soldiers (K1) and the fact that two different commanders gave different reactions to the same behaviors (K2) are the factors that detract soldiers from voluntary behaviors. Soldiers, who got reaction because of their behaviors (K6, K7), stated that they will not attempt to exhibit such behaviors next time. Besides them, that the military's response to his bad behavior is to show everyone, regardless of they are good soldiers, is one of the factors affecting the soldiers negatively. Soldiers, who got reaction due to their behaviors, stated that they would never attempt to exhibit such behaviors. Apart from these, that commanders encumber everybody and get angry just because of a fault caused by one soldier is one of the situations that affect soldiers negatively.

There are also expectations of soldiers from their fellows, as well as commanders. Soldiers stated that when there were strong bonds of friendship, they would be more willing. K1's statement that "The fact that bonds of friendship between us are weak prevents me from doing voluntary behaviors", and K4's expression of "A good friendship environment provides the rise of devotion" are the indicators of the fact that this bond is important. If soldiers perceive their fellows as impassive, their devotions drop in the same proportion. K8 said that "My friends' impassive attitudes in company affect me adversely, I feel myself as if I was a dupe", K9 stated that "Some of 
my friends remain unresponsive to the orders given by our commanders; I get angry and resent this situation. I don't feel like doing something".

\section{DISCUSSION AND CONCLUSION}

In Armies in our date, to work for the good of group by extracting duty from the situation and to execute these tasks without any order are the most important factors in both functioning administrative activities and in success of battlefields. Even if the armies are equipped with the best technology in the world, the element using this technology is "human". For this reason, the effectiveness of troops that have no higher morale, whose loyalties are weak, of which senses of solidarity are ignored, and that are not well-motivated will be low.

No study on soldiers has been found in literature. In other studies on public and private sector employees, the antecedents emerging frequently are the fairness, emotional commitment, trust, being appreciated, being supported by managers and colleagues, and job satisfaction (Morisson, 1994, p.1547; Kim \& Mauborgne, 1996, p.500; Scholl, 1981; Witt \& Wilson, 1989, p.248; Vey \& Campbell, 2004, p.120). Besides them, the character (altruist character, empathy and responsibility characteristics) is presented as one of the important antecedents (Penn, 2002; Finkelstein, 2011, p.19). Although similar results have been found, it has been observed that the friendship, development of other soldiers, learning new information, and presenting soldiers' civil life knowledge and skills to the military service are the antecedents of extra-role behaviors of the soldiers. As stated in study of Organ (1997), the positive and significant effect of social and psychological environment on voluntary behaviors are also observed on the soldiers. The one that also comes to the fore within the frame of this sample is the sphere of positive friendship. It has been seen that the most motivating factor, which enables them to exhibit these kinds of behaviors, is friendship. Prior to efficiency of works in institute or unit, friend affection and altruist/helpful, hardworking and open-to-learning personality traits are important antecedents of these behaviors. Apart from these, being liked and regarded by commanders are among the expectations of soldiers as a results of these behaviors. The factors that encourage these behaviors are seen as justice perception, commander's understanding and appreciative attitude, intimate friendship environment, while the hindering factors are injustice, indifferent attitudes of other soldiers, aggressive responses and behaviors of commanders. Within the context of these results, the fact that commanders strengthen loyalty of soldiers to each other's, encourage cooperation and solidarity, exhibit more fair, empathetic attitudes and behaviors, care about the positive and negative feedback are important. These findings accord with "3-factor theory" that is required for employees to be more enthusiastic (Sirota et al., 2005). In this context, it is possible to ensure soldiers to be volunteers only by reaching their hearts. In the context of positive organizational behavior, it may be reached to key information with studies which will be executed on this sample on behalf of providers of this motivation and soldiers may be ensured to reach a motivation to serve much more. In leadership training for commanders, moving from findings of such a research may provide more benefit than theoretical approaches do. So, increasing number of researches on soldiers must be taken into account seriously and be encouraged for development of theories and hypotheses that are specific to military service. 


\section{REFERENCES}

Barbuta, J. E. \& Story, J. S. P., (2011). "Work Motivation and Organizational Citizenship Behaviors", Journal of Leadership Studies, 5(1): 23-34.

Bateman, T. S., \& Organ, D. W. (1983). "Job satisfaction and the good soldier: The relationship between affect and employee citizenship" Academy of Management Journal, 26: 587-595.

Belogolovsky, E. \& Somech, A. (2010). “Teachers' Organizational Citizenship Behavior: Examining the Boundary between In-Role Behavior and Extra-Role Behavior from the Perspective of Teachers, Principals and Parents", Teaching and Teacher Education, 26: 914-923.

Bettencourt, L. A. \& Brown, S. W. (1997). “Contact Employees: Relationships among Workplace Fairness, Job Satisfaction and Prosocial Service Behaviors", Joumal of Retailing, Volume 73(1): 39-61.

Bowling N. A., (2010). "Effects of Job Satisfaction and Conscientiousness on ExtraRole Behaviors", Journal of Business Psychology, 25:119-130.

Brief, A. P. \& Motowidlo, S. J., (1986). "Prosocial Organizational Behaviors", Academy of Management Review, 11 (4), 710-725.

Çetin, F., \& Fikıikoca, A. (2010). "Rol Ötesi Olumlu Davranışlar Kişisel Ve Tutumsal Faktörlerle Öngörülebilir Mi?” Ankara Üniversitesi SBF Dergisi, 65(4): 41-66.

Çetin, F., Şeşen, H. \& Basim, N. (2012). "Örgüt Kültürünün Rol Ötesi Olumlu Davranışlara Olan Etkisi: Örgütsel Bağlılığın Aracı Değişken Rolü”, Doğuş Üniversitesi Dergisi, 13(2): 197 - 211.

Chen Z., Eisenberger R., Johnson, K. M., Sucharski, I. L. \& J. Aselage, (2008). "Perceived Organizational Support and Extra- Role Performance: Which Leads to Which?” The Journal of Social Psychology, 148(2): 119-124.

Chiaburu, D. S. \& Marinova, S. V. \& Lim, A. S (2007). "Helping and proactive extrarole behaviors: The influence of motives, goal orientation, and social context", Personality and Individual Differences, 43: 2282-2293.

Davoudi, S. M. M., (2012). "Organizational commitment and extra-role behaviour: A survey in Iran's Insurance Industry", Journal of Business Systems, Governance and Ethics, 7(1): 66-75.

Dyne, V. L., \& Cummings, L. L. (1990). "Extra-role behaviors: In pursuit of construct and definitional clarity". Paper presented at the annual meeting of the Academy of Management, San Francisco

Dyne, V. L., \& Lepine, J.A. (1998). "Helping and voice extra-role behaviors: Evidence of construct and predictive validity", Academy of Management Journal, 37: 765802.

Dyne V. L., Graham, J. W., \& Dienesh, R. M. (1994). “Organizational citizenship behavior: construct redefinition, measurement and validity", Academy of Management Journal, 37: 765-802 
Finkelstein, M. A., (2011). "Intrinsic and Extrinsic Motivation and Organizational Citizenship Behavior: A Functional Approach to Organizational Citizenship Behavior", Journal of Psychological Issues in Organizational Culture, 2(1): 19-34.

Hannah, S.T., Avolio, B.J. \& Walumbwa, F.O. (2011). "Relationships between Authentic Leadership, Moral Courage, and Ethical and Pro-Social Behaviors" Business Ethics Quarterly, 21(4): 555-578.

Kane, R. E., Magnusen, M. J. \& Perrewe, P. L. (2012). "Differential effects of identification on extra-role behavior", Career Development International 17(1): $25-42$

Katz, D. (1964). "The motivational basis of organizational behavior", Behavioral Science, 9: 131-146.

Kim, W. C. \& Mauborgne, R. A. (1996). "Procedural Justice and Managers' In-Role and Extra-Role Behavior: The Case of the MultinationalAuthor(s):, Management Science, 42(4): 499-515.

Karaman, A. \& Aylan, S. (2012). "Örgütsel Vatandaşl1k, Kahramanmaraş Sütçü İmam Üniversitesi İktisadi ve İdari Bilimler Fakültesi Dergisi, 1:35-48.

Leung A. S. M., (2008) "Matching Ethical Work Climate to In-role and Extra-role Behaviors in a Collectivist Work Setting”, Journal of Business Ethics, 79: 43-55.

Morrison, E. (1994), "Role Definitions and Organizational Citizenship Behavior: The Importance of the Employee's Perspective", Academy of Management Journal, 37(6): 1543-1567.

Morrison, E. W., \& Phelps, C. C. (1999). Taking charge at work: Extra-role efforts to initiate workplace change. Academy of Management Journal, 42, 403- 419.

Organ, D. W., (1988). Organizational Citizenship Behavior: The Good Soldier Syndrome, Canada: Lexington Books.

Organ, D. W., (1990), "The Subtle Significance of Job Satisfaction," Clinical Laboratory Management Review, 4 (1), 94-98.

Organ. D. W. (1997). “Organizational citizenship behavior: It's construct clean-up time", Human Performance, 10: 85-97.

Penner, L. A. (2002). "Dispositional and organizational influences on sustained volunteerism: An interactionist perspective", Journal of Social Issues, 58: 447467.

Penner, L.A., Midili, A.R. \& Kegerlmeyer, J. (1997), "Beyond job attitudes: a personality and psychology perspective on the causes of organizational citizenship behavior", Human Performance, 10(2): 111-131.

Podsakoff, P. M., Mackenzie, S. B., Paine, J. B., \& Bachrach, D. G., (2000). "Organizational Citizenship Behaviors: A Critical Review of the Theoretical and Empirical Literature and Suggestions for Future Research", Journal of Management, 26(3): 513-563.

Scholl, R.W. (1981). "Differentiating organizational commitment from expectancy as a motivating force", Academy of Management Review, 6: 589-599. 
Sirota, D., Mischkind, L. A., Meltzer M. I., (2005). The Enthusiastic Employee: How Companies Profit by Giving Workers What They Want. Wharton School Publishing, United State of America.

Somech, A. \& Zahavy, A. D. (2000). "Understanding extra-role behavior in schools: the relationships between job satisfaction, sense of efficacy, and teachers' extra-role behavior" Teaching and Teacher Education, 16: 649-659.

Stoner, J., Perrewe, P. L. \& Munyon, T. P. (2011). "The role of identity in extra-role behaviors: development of a conceptual model", Journal of Managerial Psychology Vol. 26(2): 94-107.

Srikanth, P. B. \& Jomon, M. G. (2013). "Is This My Job at All?" The Impact of Flexible Role Orientation in Predicting Extra-Role Behavior", Southern Business Review, Summer: $29-48$.

Tremblay, M., Cloutierb, J. Simardb, G., Cheneverta, D. \& Vandenberghe, C. (2010). "The role of HRM practices, procedural justice, organizational support and trust in organizational commitment and in-role and extra-role performance", The International Journal of Human Resource Management, 21(3): 405-433.

Turnipseed, D.L., \& Rassuli, A., (2005). "Performance perception of organizational citizenship behaviors at work: a bi-level study among managers and employee", British Journal of Management, 16: 231-244.

Vey, M. A \& Campbell, J. (2004). "In-Role and Extra-Role Organizational Citizenship Behavior: Which Are We Measuring”, Human Performance, 17(1): 119-135.

Yeşiltaş, M. Kanten, P. \& Sormaz, Ü. (2013). “Otantik liderlik tarzının prososyal hizmet davranışları üzerindeki etkisi: Konaklama işletmelerine yönelik bir uygulama", İstanbul Üniversitesi İşletme Fakültesi Dergisi, 42(2): 333-350.

Waldman, D. A., (1994), "The Contributions of Total Quality Management to a Theory of Work Performance", Academy Management Review, 19(3): 510-536.

Witt, L. A. \& Eilson, J. W. (1991). "Moderating Effect of Job Satisfaction on The Relationship between Equity and Extra-role Behaviors", The Journal of Social Psychology, 131(2): 247-252.

Zhu, Y., (2013). "Individual Behavior: In-role and Extra-role”, International Journal of Business Administration, 4(1): 23-27. 